\title{
Study on Adoption of Improved Technology among Basmati Rice Growers in Sehore District of Madhya Pradesh, India
}

\author{
Jitendra Varma ${ }^{1}$, Subhash Rawat ${ }^{2}$, M.K. Gupta ${ }^{1}$ and Himanshu Tembhre ${ }^{3 *}$ \\ ${ }^{1}$ College of Agriculture, Khandwa, RSKVV, Gwalior M.P., India \\ ${ }^{2}$ Krishi Vigyan Kendra, Khandwa, RSKVV, Gwalior M.P., India \\ ${ }^{3}$ District co-coordinator, National Food Security Mission, Balaghat, M.P., India
}

*Corresponding author

\section{A B S T R A C T}

\begin{tabular}{|c|}
\hline Keywords \\
\hline $\begin{array}{l}\text { Basmati rice } \\
\text { growers, Adoption, } \\
\text { chi square test }\end{array}$ \\
\hline Article Info \\
\hline $\begin{array}{l}\text { Accepted: } \\
04 \text { April } 2018 \\
\text { Available Online: } \\
10 \text { May } 2018\end{array}$ \\
\hline
\end{tabular}

\section{Introduction}

Paddy (Oryza sativa) is grown all over the world and is staple food for more than half of the world population. India is the second leading producer of rice in the world. In India, rice is grown on an area of 2.5 million hectares with a production of about 6.25 million tons, while in Madhya Pradesh State, the area under rice was 0.0000021 million hectare with production of 0.00000105 million tones. There are many problems associated with adoption of recommended farm practices which may be related to socio-economic status of farmers, technological, financial etc which
The present study was conducted at Budni block of Sehore district of Madhya Pradesh. The findings of the research revealed that, improved production technology of Basmati rice growers, the extent of adoption was found to be maximum (43.64 \%) in case of transplanting and harvesting. On the other hand nursery management and pest management practices showed minimum extent of adoption $(25.46 \%)$. The study also ficated that socio-economic factors like age, education, land holding, annual income, farm power and implement, social participation, economics motivation, scientific orientations, marketing orientations, contact with extension agent, mass media exposure and knowledge level were positively and significantly associated with the extent of adoption of rice growers at $0.05 \%$ level of significance, whereas caste and material possession had non-significant relationship with the level of adoption. Thus the study highlighted the high adoption of improved production technology of basmati rice crop.

need to be addressed. These problems reflect the quality of advisory services provided to the small farmers. Rice yield may be increased by adoption of improved rice varieties which have potential to improve nutrition, promote rural development and support sustainable development. These recommended practices must be followed in totality according to the location specific problems of the area. Excessive and imbalanced use of inorganic fertilizers has adversely affected the soil causing decrease in organic carbon, reduction in microbial flora and fauna of soil, increasing acidity and alkalinity and hardening of soil. Moreover, excessive uses of nitrogenous and 
phosphate fertilizers are contaminating water bodies thus affecting health hazards for human beings and animals. Small farmers due to negligence tend to apply over doses of fertilizers, insecticides etc. with the expectation of obtaining higher yields. Therefore, there is need for more strict control on the over adoption of recommended practices related to land preparation, planting, management of water, application of fertilizers, control of weeds, control of insect pests and harvesting. The scope for expanding rice production lies in enhancing productivity. Research studies have clearly established that the adoption of recommended rice technology gives high yields and thus income to the rice growers. Keeping in mind this context, the study was conducted in Sehore District of Madhya Pradesh State with the specific objectives to study the profile of basmati rice growers, adoption of basmati rice growers regarding the improved production technology of basmati rice crop, association between profile of basmati rice growers and their adoption.

\section{Materials and Methods}

The study was conducted in block consists of 141 villages, out of which 5 villages were randomly selected. A list of farmers from selected villages, who are growing basmati rice crop was prepared with the help of agriculture extension officials working in study area. Respondents were selected by using proportionate random sampling method to make the total sample size 110 . For the primary data were collected personally by interviewed schedule. The secondary data were collected from Department of Agriculture. The respondents were asked to give opinion about the use of recommended paddy growing practices (adoption)on three point continuum viz; always, some times and never and scores 2, 1 and 0 were assigned, respectively. Extent of adoption was calculated on the basis of these scores. Similarly the constraints faced by the rice growers were also recorded on the two point continuum namely yes and no. The data were analyzed using frequency, percentage, chisquare test and association between dependent and independent variables.

\section{Results and Discussion}

\section{Socio-economic profile of the respondents}

The data revealed that majority of respondents $(53.64 \%)$ were in middle age followed by old $(23.63 \%)$, and young age $(22.73 \%)$ category (Table 1). As old age farmers have almost fixed behavior patterns, so middle aged and especially young farmers must be targeted for imparting skill trainings in rice production technologies.

The respondents were having medium level $(29.09 \%)$ of education followed by high level $(27.29 \%)$ and primary level $(21.81 \%)$ of education. The respondents were majority of Basmati rice growers $(45.45 \%)$ belongs to Other Backward Classes (OBC) followed by general $(23.64 \%)$, while about schedule tribes $(16.36 \%)$ and schedule caste $(14.55 \%)$.

The maximum number of Basmati rice growers $(45.45 \%)$ revealed that having medium size group of land holdings (range 2.1 to 4.00 ha.), whereas maximum Basmati rice growers $(58.18 \%)$ were found having low annual income up to Rs. 2.50 lakh. The table also revealed that, the maximum numbers of Basmati rice growers $(43.64 \%)$ were found having low farm power and implements. The findings regarding material possession revealed that, the maximum numbers of Basmati rice growers $(41.83 \%)$ were having medium material possession. Social participation of Basmati rice growers was higher in number $(45.46 \%)$ in medium category. 
Table.1 Socio-economic profile of Basmati rice growers

\begin{tabular}{|c|c|c|c|}
\hline Variables & Characteristics & No. of respondents & Percentage \\
\hline Age & $\begin{array}{l}\text { Young age (up to } 35 \text { years) } \\
\text { Middle age ( } 36 \text { to } 55 \text { years) } \\
\text { Old age (above } 56 \text { years) }\end{array}$ & $\begin{array}{l}25 \\
59 \\
26\end{array}$ & $\begin{array}{l}22.70 \\
53.64 \\
23.63\end{array}$ \\
\hline Education & $\begin{array}{l}\text { Primary School } \\
\text { Middle School } \\
\text { High and higher secondary school }\end{array}$ & $\begin{array}{l}24 \\
32 \\
30\end{array}$ & $\begin{array}{l}21.81 \\
29.09 \\
27.29\end{array}$ \\
\hline Caste & $\begin{array}{l}\text { Scheduled tribes } \\
\text { Scheduled caste } \\
\text { Other backward classes } \\
\text { General }\end{array}$ & $\begin{array}{l}18 \\
16 \\
50 \\
26\end{array}$ & $\begin{array}{l}16.36 \\
14.55 \\
45.45 \\
23.64\end{array}$ \\
\hline Land holding & $\begin{array}{l}\text { Small (up to } 2 \text { ha) } \\
\text { Medium ( } 2.01 \text { to } 4 \text { ha) } \\
\text { Large (above } 4 \text { ha) }\end{array}$ & $\begin{array}{l}23 \\
50 \\
28\end{array}$ & $\begin{array}{l}29.10 \\
45.45 \\
25.45\end{array}$ \\
\hline Annual income & $\begin{array}{l}\text { Low (Rs. up to } 2.50 \text { lakh) } \\
\text { Medium (Rs. } 2.51 \text { to } 4.60 \text { lakh) } \\
\text { High (Rs. } 4.61 \text { to } 6.70 \text { lakh) }\end{array}$ & $\begin{array}{l}64 \\
26 \\
20\end{array}$ & $\begin{array}{l}58.18 \\
23.64 \\
18.18\end{array}$ \\
\hline $\begin{array}{l}\text { farm power and } \\
\text { implements }\end{array}$ & $\begin{array}{l}\text { Low (score up to } 4) \\
\text { Medium (score } 5 \text { to } 8) \\
\text { High (score } 9 \text { to } 12)\end{array}$ & $\begin{array}{l}48 \\
33 \\
29\end{array}$ & $\begin{array}{l}43.64 \\
30.00 \\
26.36\end{array}$ \\
\hline Material Possession & $\begin{array}{l}\text { Low (score up to } 3) \\
\text { Medium (score } 4 \text { to } 6) \\
\text { High (score } 7 \text { to } 9 \text { ) }\end{array}$ & $\begin{array}{l}30 \\
46 \\
34\end{array}$ & $\begin{array}{l}27.28 \\
41.82 \\
30.90\end{array}$ \\
\hline Social Participation & $\begin{array}{l}\text { Low }(\text { score up to } 5) \\
\text { Medium(score } 6 \text { to } 10) \\
\text { High (score } 11 \text { to } 15)\end{array}$ & $\begin{array}{l}28 \\
50 \\
32\end{array}$ & $\begin{array}{l}25.45 \\
45.46 \\
29.09\end{array}$ \\
\hline Economic motivation & $\begin{array}{l}\text { Low (score } 6 \text { to } 18 \text { ) } \\
\text { Medium (score } 19 \text { to } 30 \text { ) } \\
\text { High (score } 31 \text { to } 42 \text { ) }\end{array}$ & $\begin{array}{l}35 \\
55 \\
20\end{array}$ & $\begin{array}{l}31.82 \\
50.00 \\
18.18\end{array}$ \\
\hline Scientific orientation & $\begin{array}{l}\text { Low (score } 6 \text { to } 18) \\
\text { Medium (score } 19 \text { to } 30) \\
\text { High (score } 31 \text { to } 42 \text { ) }\end{array}$ & $\begin{array}{l}34 \\
51 \\
25\end{array}$ & $\begin{array}{l}30.90 \\
46.37 \\
22.73\end{array}$ \\
\hline Marketing orientation & $\begin{array}{l}\text { Low (score up to } 2) \\
\text { Medium(score } 3 \text { to } 4) \\
\text { High(score } 5 \text { to } 6)\end{array}$ & $\begin{array}{l}16 \\
60 \\
34\end{array}$ & $\begin{array}{l}14.55 \\
54.55 \\
30.90\end{array}$ \\
\hline Mass media exposure & $\begin{array}{l}\text { Low(score up to } 5) \\
\text { Medium(score } 6 \text { to } 10) \\
\text { High (score } 11 \text { to } 14 \text { ) }\end{array}$ & $\begin{array}{l}28 \\
47 \\
35\end{array}$ & $\begin{array}{l}25.45 \\
42.73 \\
31.82\end{array}$ \\
\hline $\begin{array}{l}\text { Extension } \\
\text { participation }\end{array}$ & $\begin{array}{l}\text { Low (score up to } 6) \\
\text { Medium(score } 7 \text { to } 12 \text { ) } \\
\text { High(score } 13 \text { to } 18)\end{array}$ & $\begin{array}{l}22 \\
40 \\
48\end{array}$ & $\begin{array}{l}20.00 \\
36.37 \\
43.63\end{array}$ \\
\hline Knowledge level & $\begin{array}{l}\text { Low (score up to } 24) \\
\text { Medium(score } 25 \text { to } 48 \text { ) } \\
\text { High(score } 49 \text { to } 72)\end{array}$ & $\begin{array}{l}21 \\
60 \\
29\end{array}$ & $\begin{array}{l}19.09 \\
54.54 \\
26.37\end{array}$ \\
\hline
\end{tabular}


Table.2 Distribution of Rice growers according to their adoption improved technology

\begin{tabular}{|l|l|c|c|}
\hline S. No. & Categories & No. of respondents & Percentage \\
\hline 1. & Low & 28 & 25.46 \\
\hline 2. & Medium & 34 & 30.90 \\
\hline 3. & High & 48 & 43.64 \\
\hline & Total & $\mathbf{1 1 0}$ & $\mathbf{1 0 0 . 0 0}$ \\
\hline
\end{tabular}

Table.3 Association between characteristics of basmati rice growers and their adoption technology

\begin{tabular}{|l|c|c|c|}
\hline Variable & Chi square value & D.F. & Co-efficient of Association \\
\hline Age & $10.82^{*}$ & 4 & $0.30++$ \\
\hline Education & $10.23^{*}$ & 4 & $0.29++$ \\
\hline Caste & $6.65 \mathrm{Ns}$ & 4 & $0.23++$ \\
\hline Land holding & $11.69^{*}$ & 4 & $0.31++$ \\
\hline Annual income & $12.31^{*}$ & 4 & $0.32++$ \\
\hline farm power and implements & $11.74^{*}$ & 4 & $0.31++$ \\
\hline Material Possession & $6.58 \mathrm{Ns}$ & 4 & $0.23++$ \\
\hline Social Participation & $12.03^{*}$ & 4 & $0.31++$ \\
\hline Economic motivation & $14.78^{*}$ & 4 & $0.34++$ \\
\hline Scientific orientation & $10.40^{*}$ & 4 & $0.29++$ \\
\hline Marketing orientation & $12.54^{*}$ & 4 & $0.32++$ \\
\hline Mass media exposure & $10.24 *$ & 4 & $0.29++$ \\
\hline Extension participation & $9.98^{*}$ & 4 & $0.28++$ \\
\hline Knowledge level & $10.09^{*}$ & 4 & $0.28++$ \\
\hline
\end{tabular}

Note: *sign indicates Significant, ++ sign indicates Fair association, Ns sign indicates Nonsignificant, + sign indicates Negligible (As evident from the data of table 3 that, the variables)

The higher percentage of Basmati rice growers $(50.00 \%)$ had medium economic motivation, whereas majority of the Basmati rice growers $(46.37 \%)$ had medium scientific orientation. Results also showed that, the maximum Basmati rice growers (54.55\%) had medium market orientation regarding their produce. About 43.64\% Basmati rice growers were having low farm power and implements facilities. Mass media exposure of Basmati rice growers was found medium $(42.73 \%)$. Extension participation revealed that, the maximum number of Basmati rice growers (43.63\%) had high extension participation. The findings regarding knowledge level inferred that, $19.09 \%$ of the Basmati rice growers had low knowledge level and maximum number of soybean growers (54.54\%) had medium level of mass media exposure. The present findings are inconformity with other reporters viz., Borthakur et al., (2015), Khan et al., (2013), and Rahangdale (2011).

\section{Adoption of rice growers regarding improvement technology}

Adoption of improved technology by the Rice growers, the study revealed that maximum number $(43.64 \%)$ of rice growers had high adoption improved technology (Mandloi, 2007). similarly, adoption improved 
technology of rice growers was studied regarding adoption of improved rice technology it was observed that lower of rice growers had low adoption improved production technology (Table 2).

\section{Association between characteristics of basmati rice growers and their adoption technology}

Association between characteristics of Basmati rice growers and their adoption improved technology like age, education, land holding, annual income, farm power and implements, social participation, economic motivation, scientific orientation, marketing orientation, mass media exposure, extension participation and knowledge level regarding the improved production technology of basmati rice crop were found to have significant association with adoption of basmati rice growers (Table 3). The similar reports were also published earlier (Borthakur et al., (2015), Chawang and Jha (2010), Khan et al., (2013), Rahangdale (2011) and Sharma et al., (2015). Further, it is also interesting to know from the analysis that, the variables like caste was found to have non-significant association with adoption of basmati rice growers. This finding is similar to that reported by Chawang and Jha (2010). The material possession of basmati rice growers had shown non-significant association with adoption of basmati rice growers.

Most of the basmati rice growers $(53.64 \%)$ belonged to middle age group (36 to 55 years), whereas in case of education level of basmati rice growers, 29.09 per cent had educated up to middle school and maximum of them belonged to Other Backward Classes $(\mathrm{OBC})$. The study revealed that, the higher percentage of basmati rice growers $(45.00 \%)$ had medium size group of land holding. As regard annual income, majority of respondents were having low annual income (up to Rs. 2.5 Lakh) and low number of farm power and implements (43.64\%). The study further depicted that, the majority of basmati rice growers had medium social participation $(45.46 \%)$ and economic motivation $(50.00 \%)$. In case of scientific orientation (46.37\%), market orientation $(54.55 \%)$ and mass media exposure $(42.73 \%)$ of basmati rice growers having medium. The study revealed that, the extension participation of basmati rice growers had high $(43.63 \%)$. In case of knowledge level, the study revealed that, the higher percentage of basmati rice growers $(43.63 \%)$ had medium knowledge level regarding the improved production technology of basmati rice crop.

\section{References}

Borthakur S., Mishra P., Talukdar R.K. and Bortamuly D. (2015). Scaling the adoption of recommended rice production technologies by the farmers in Assam State. Indian Res. J. Exten. $E d u, 15$ (2): 32-37

Chawang J.K. and Jha K.K. (2010). Training needs of paddy cultivators in Nagaland. Indian Res. J. Exten. Edu, 10 (1): 74-77

Khan M.A., Jeong K.wang Hwa Karim A.S., Kim Eunjong M.Z. and Muttaquinur Rahman (2013). Adopter category in respect to a transplanted monsoon rice variety in two selected villages of Bangladesh. J. Agri. Sci. (Toronto), 5(3): 200-216

Mandloi R.S. (2007). A comparative study on adoption of soybean production technology in high and low productive block of Dhar district, M.P. M.Sc. (Ag.), Thesis, JNKVV, Jabalpur.

Rahangdale Deepti (2011). A study on impact of system of rice intensification (SRI) method of paddy cultivation on production level in Balaghat block of district Balaghat (M.P.). M.Sc. (Ag.) Thesis JNKVV, Jabalpur. 
Sharma Karamjit, Dhaliwal N.S. and Kumar Ajay. (2015). Analysis of adoption and constraints perceived by small paddy growers in rice production technologies in Muktsar district of Punjab State, India. Indian J. Exten. Edu. 15 (2): 2023.

\section{How to cite this article:}

Jitendra Varma, Subhash Rawat, M.K. Gupta and Himanshu Tembhre. 2018. Study on Adoption of Improved Technology among Basmati Rice Growers in Sehore District of Madhya Pradesh, India. Int.J.Curr.Microbiol.App.Sci. 7(05): 352-357. doi: https://doi.org/10.20546/ijcmas.2018.705.045 